\title{
Local Government Financing Platforms in China: A Fortune or Misfortune?
}

Yinqiu Lu and Tao Sun 


\title{
IMF Working Paper
}

European Department and Monetary and Capital Markets Department

\section{Local Government Financing Platforms in China: A Fortune or Misfortune ${ }^{1}$ Prepared by Yinqiu Lu and Tao Sun}

\author{
Authorized for distribution by Laura Kodres and Julie Kozack
}

October 2013

\section{This Working Paper should not be reported as representing the views of the IMF.} The views expressed in this Working Paper are those of the author(s) and do not necessarily represent those of the IMF or IMF policy. Working Papers describe research in progress by the author(s) and are published to elicit comments and to further debate.

\begin{abstract}
China's rapid credit expansion in 2009-10 brought local government financing platforms (LGFPs) into the spotlight. This paper discusses their function, reasons behind their recent expansion, and risks they are posing to the financial sector, local governments, and sovereign balance sheet. This paper argues that LGFPs were a fortune for China in the past, but would turn out to be a misfortune if the causes of the rapid expansion of LGFPs are not addressed promptly. In this context, the paper proposes ways to avoid misfortune by: acknowledging and addressing the revenue and expenditure mismatches at the local government level; establishing a comprehensive framework to regulate and supervise local government budgets; ensuring the sustainability of the financial resources obtained from the sale of land use rights; and developing local government bond markets and promoting financial reforms.
\end{abstract}

JEL Classification Numbers: E50, G21, H30, H70

Keywords: Credit, local government, sovereign risk, fiscal policy, and capital markets Author's E-Mail Address:ylu@imf.org; tsun@imf.org

\footnotetext{
${ }^{1}$ We would like to thank to Laura Kodres and Julie Kozack for their helpful comments and suggestions. All remaining errors are our own.
} 


\section{Contents}

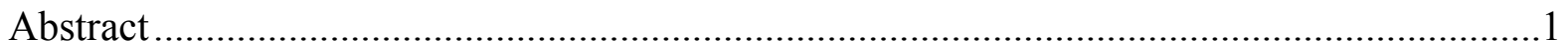

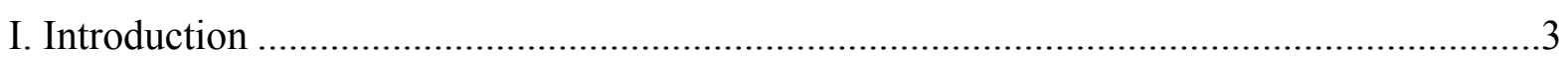

II. The Function of LGFPs and Their Relationship with Local Governments ..........................

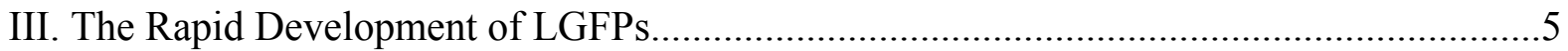

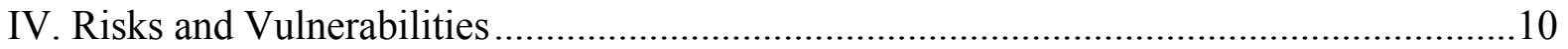

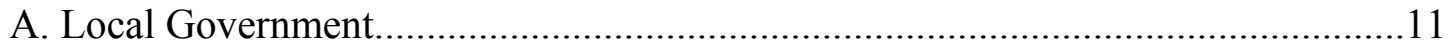

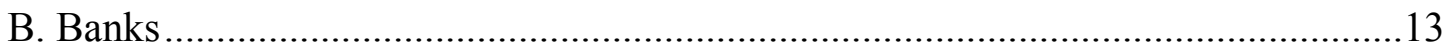

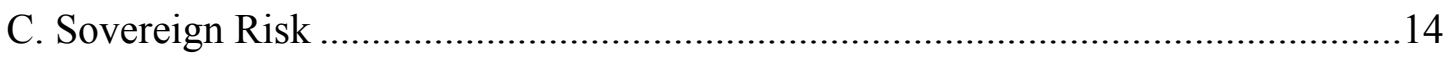

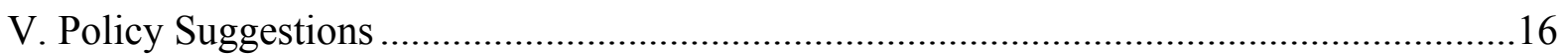

A. Addressing the Fiscal Revenue and Expenditure Mismatches ................................17

B. Establishing a Comprehensive Framework to Regulate and Supervise Local

Government Budget and Financing …………………….......................................19

C. Ensuring the Sustainability of Land Capitalization Process ……………………......22

D. Developing Local Government Bonds into Safe Assets ..........................................24

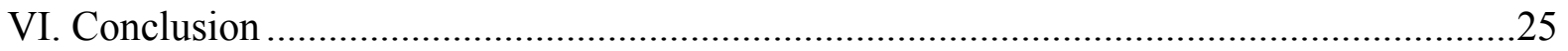

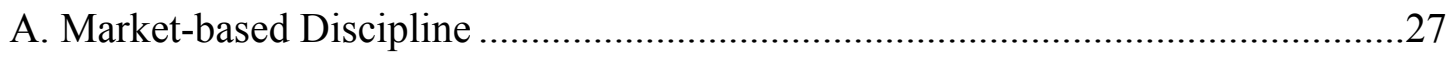

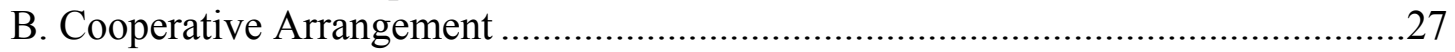

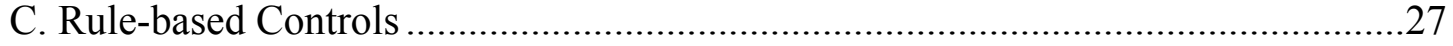

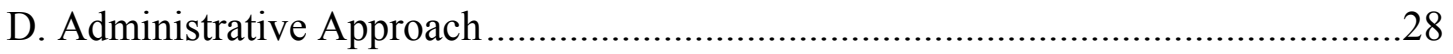

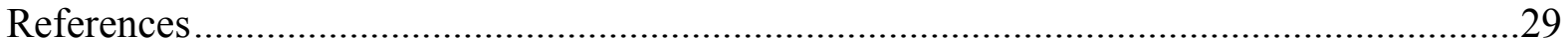

Tables

1. Chinese Banks' Exposures to LGFPs and Potential Incremental Gross NPL Ratios ...........14

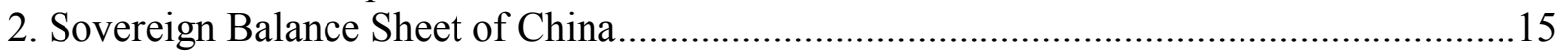

3. Revenue Categories: Property Taxes .......................................................................... 18

Figures

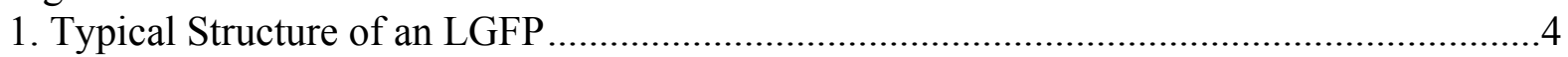

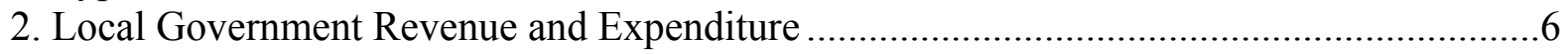

3. Fiscal Gap at Province Level ..........................................................................................

4. Shares of Local Government Revenue/Expenditure in General Government

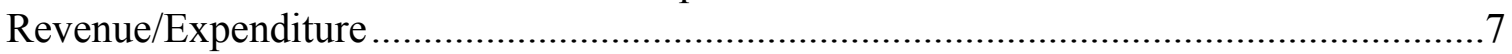

5. Land Sales Revenue as a Share of Local Government Revenue ........................................ 8

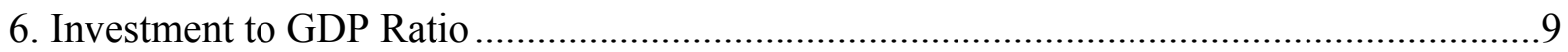

7. Transfer-adjusted Expenditure and Revenue Gap by Province .............................................

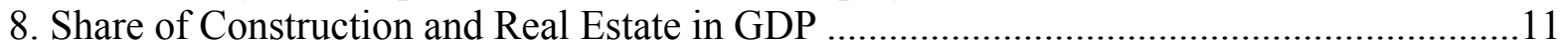

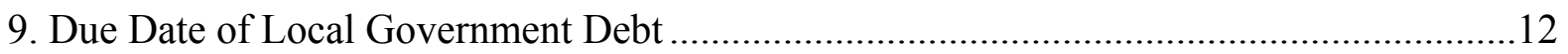

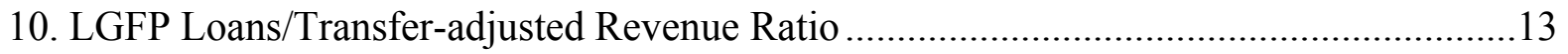

11. Loan Composition in the Banking System ..................................................................14

12. A Comparison of Deficits to GDP Ratios between Chinese Provinces and Several High

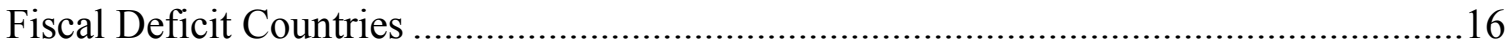

13. Composition of Urban and Rural Housing and Construction Land...................................22

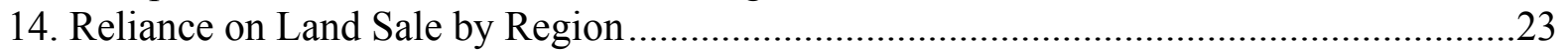

15. Expected Decline in Available Land and Land Sales Revenue........................................24 


\section{INTRODUCTION}

1. Local government financing platforms (LGFPs) are the backbone of local governments in promoting infrastructure development in China. As the principal financing agents for local governments, their crucial role in upgrading China's infrastructure and promoting economic growth has been widely acknowledged. By not encouraging higher local fiscal deficits or imposing more pressure on local government to issue bonds, LGFPs could, to some extent, be seen as a fortune for Chinese local governments, as they act as a vehicle to provide off-balance sheet quasi-fiscal support for local governments.

2. The rapid credit expansion in 2009-10 brought LGFPs into the spotlight. To shield the domestic economy from the financial crisis, at the end of 2008 the Chinese authorities started to implement fiscal stimulus measures and ease monetary policy. The stimulus measures provided a strong impetus for local governments to spend on infrastructure to generate growth and create employment. Given their limited revenue base and prohibition from direct borrowing from financial markets by the Budget Law, local governments relied increasingly on LGFPs to channel funding for infrastructure spending. The rapid expansion of LGFPs may turn the fortune to a misfortune as the resulting rapid credit expansion to LGFPs triggered concerns regarding local governments' indebtedness, banks' asset quality, and, more broadly, medium-term financial stability and sovereign risk in China, if the causes of rapid expansion are not addressed.

3. This paper explores the function of LGFPs and the reasons behind their recent expansion (Sections II and III). We argue that the relationship between LGFPs and local governments is intertwined, and LGFPs' rapid growth results from an economy that relies heavily on investment; a large government role in the economy; revenue and expenditure mismatches (at the local government level) exacerbated by the fiscal stimulus; and banks' weak risk management and internal controls.

4. The rapid development of LGFPs has made the economy subject to the volatility of the real estate market and further distorted the economic structure (Section IV). At end 2010, the debt by LGFPs amounted to RMB 4.97 trillion, equivalent to two thirds of the sum of total local government revenue and transfers from the central government. Moreover, since the receipts from the sale of land lease rights are the main sources for debt repayment, a correction in real estate prices could hurt the debt servicing ability of local governments and LGFPs, and impair banks' asset quality. In the worst case scenario, it may trigger contagion between the financial sector and the sovereign.

5. The proliferation of LGFP debts and their consequences make it essential to understand the causes of their rapid development, address the risks, and more importantly, implement measures to prevent a similar phenomenon from recurrence (Section V). Given that discussion of China's economic growth model and monetary and financial framework is beyond the scope of this paper, the suggestions raised in the paper 
cover four areas. First, the mismatches between revenue and expenditure at the local government level should be fully acknowledged and addressed. Second, there is a need to establish a comprehensive framework to regulate and supervise local government budget and financing. Third, it is important to ensure that the financial resources obtained from the sale of land are sustainable given the constrained land supply in the medium term, which requires a comprehensive strategy for land capitalization. Finally, encouraging the issuance of local government bonds and developing them into safe assets can also help to make the land capitalization process sustainable and thus alleviate sovereign risk by cutting the transmission of contingent risk from local governments to the central government.

\section{THE FUnCTION OF LGFPS AND THEIR RELATIONSHIP WITH LOCAL GOVERNMENTS}

\section{LGFPs provide local governments with corporate platforms to pursue local} infrastructure projects. Treated as municipal state-owned enterprises (SOEs) under China's Company Law, LGFPs are the backbone of local governments in promoting infrastructure development in China. They are primarily engaged in the construction of public welfare projects, such as affordable housing construction, infrastructure, social services, and ecological and environmental protection.

Figure 1. Typical Structure of an LGFP

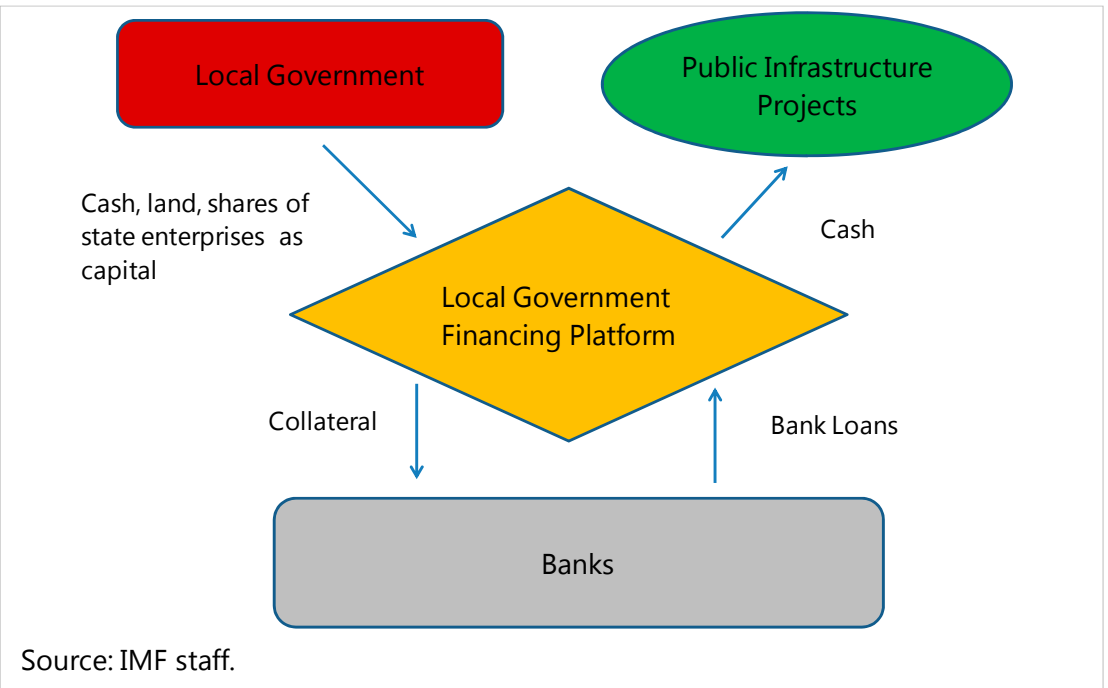

7. The relationship between local governments and LGFPs is intertwined. Once LGFPs have been set up, local governments provide capital to them through budget revenue injection, transfer of land use rights and existing assets, such as roads and bridges, or receipts for bonds issued by the central government on behalf of local governments (Figure 1). Once LGFPs have met their capital requirement, they finance the rest through bank lending or raising funding from equity or bond markets. Basically, they act as principal financing agents for local governments, given that the latter are statutorily prohibited from engaging in direct market borrowing, including bank loans. 


\section{Local governments' fiscal position is often included as one criterion used by} banks to assess the creditworthiness of LGFPs. Apart from assessing the stand-alone repayment capacity of individual companies or projects, banks also evaluate the regional economic situation, the respective industries of the specific LGFP investments - including sectoral support from the central government — and local governments' aggregate fiscal position. By taking into account local governments' financial health, banks implicitly or explicitly assume that local governments would be ultimately responsible for LGFPs' liabilities.

\section{Local government support is essential for LGFPs with limited cash flows. Some}

LGFPs are profitable and have operating income to make loan and debt repayments, making them banks' preferred customers, but other LGFPs need support from local governments. To support them, local governments usually transfer land as collateral to help LGFPs secure loans. Land could also provide future operating revenue for LGFPs when the land use rights are sold in the future. In some cases, local governments have set aside future revenues to provide subsidies for LGFPs. To enhance the legitimacy of such support, local governments often include these subsidies in the local budget, which is approved by the local national congress. In addition, explicit local government guarantees also facilitate LGFP borrowing.

\section{THE RAPID DEVELOPMENT OF LGFPS}

\section{LGFPs grew rapidly amid the 2008-09 credit expansion after relatively limited} activities in previous years. These companies are the reincarnation of the trust and investment companies of the 1990s, which helped local governments raise funds from both domestic and overseas investors. For a time in the late 1990s, the central government forced the closure of thousands of trust and investment companies. However, local fiscal shortfalls due to taxation centralization and local officials' strong incentive to promote investment propelled the "rebirth" of local trusts in the form of LGFPs. China's massive response to the 2008-09 global financial crisis triggered a rapid proliferation of LGFPs (Shin, 2010). By mid-2009, at least 3,800 LGFPs have formed at the provincial, prefectural, and even at the county/city district level (Meng 2009). According to the National Audit Office of the People's Republic of China (NAO) in June 2011, ${ }^{2}$ the stock of local government debt reached RMB 10.7 trillion as of end-2010 (equivalent to 27 percent of GDP in 2010), in which LGFP debt was around RMB 4.97 trillion. The China Banking Regulatory Commission (CBRC) estimated that loans to LGFPs stood at RMB 9.2 trillion as of end-2012. In July 2013, the NAO announced that it would conduct a national survey of local government debts again. Though a higher level of local government debts is expected owing to a wider coverage, the features of the recent development would be roughly the same as before.

\footnotetext{
${ }^{2}$ National Audit Office of People's Republic of China (2011).
} 


\section{The recent rapid development of LGFPs exposes it to a mismatch between} revenue and expenditure of local governments. Since 1994, the central government has rapidly centralized the most lucrative sources of revenue, including value-added tax (VAT), resource tax, and personal and enterprise income tax. ${ }^{3}$ In 2002, the central government further ordered local governments to channel 50 percent of personal and enterprise income tax to the central government. Nevertheless, local spending responsibilities remained roughly unchanged. As a result, the imbalances between local government revenue and expenditure have widened (Figure 2) and vary among provinces (Figure 3). Such mismatch is relatively high compared with other countries (Figure 4). During normal times, this mismatch can be largely met by local governments by a request for additional central government transfers, ${ }^{4}$ and by generating extra budgetary revenues, dominated by land sales revenue (Figure 5 ). ${ }^{5}$

Figure 2. Local Government Revenue and Expenditure

(In percent of general government revenue and expenditure)

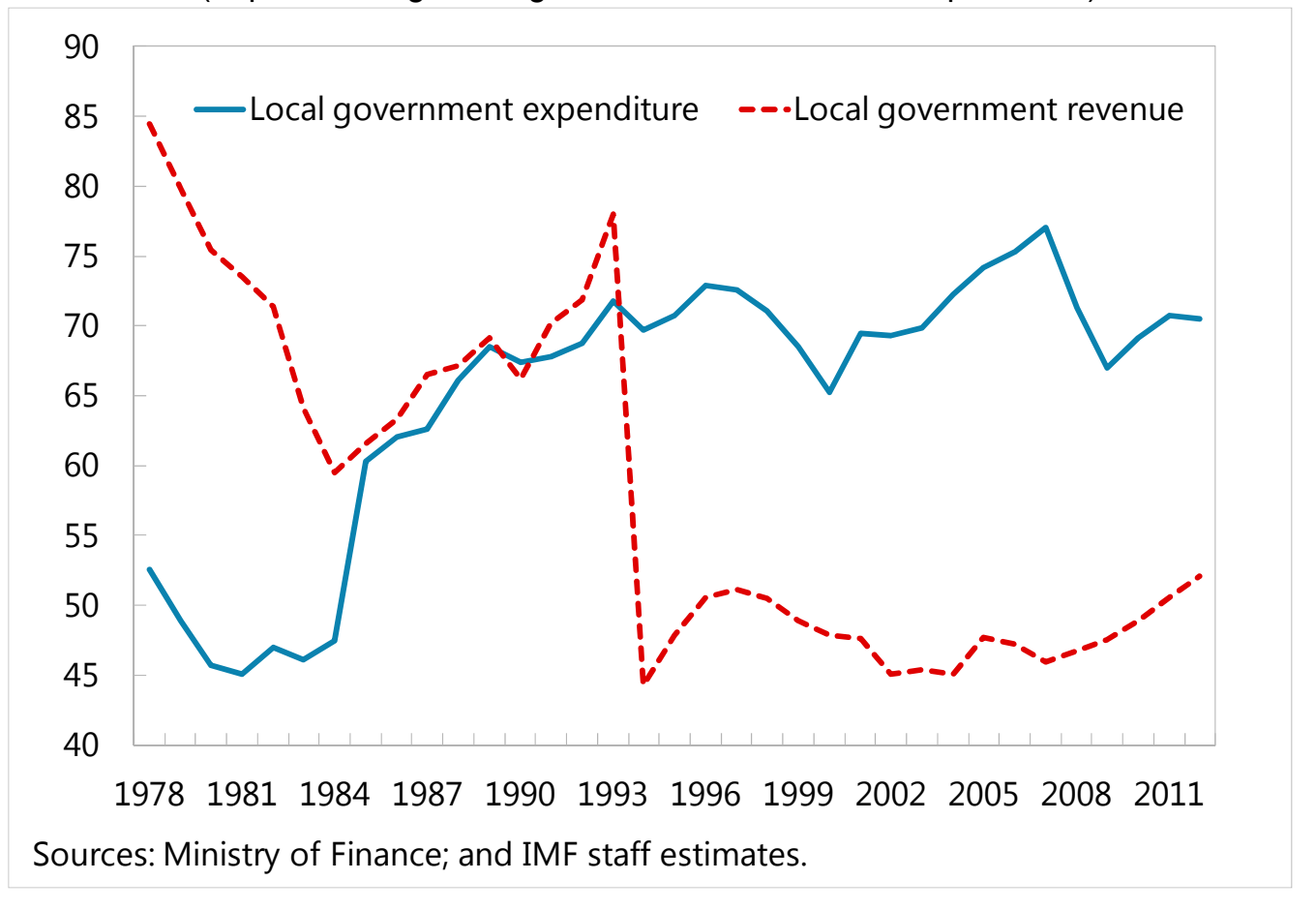

\footnotetext{
${ }^{3}$ In the case of VAT, the four layers of local governments - provincial, prefectural/city, county, and townshiptogether share only 25 percent of VAT revenue.

${ }^{4}$ However, the competitive bidding process for transfers makes it hard for local governments to obtain sufficient transfers to match the gap in time.

${ }^{5}$ Land sales revenue is the revenue from the sale of land use rights.
} 
Figure 3. Fiscal Gap at Province Level

(In percent of revenue, 2006-11 annual average)

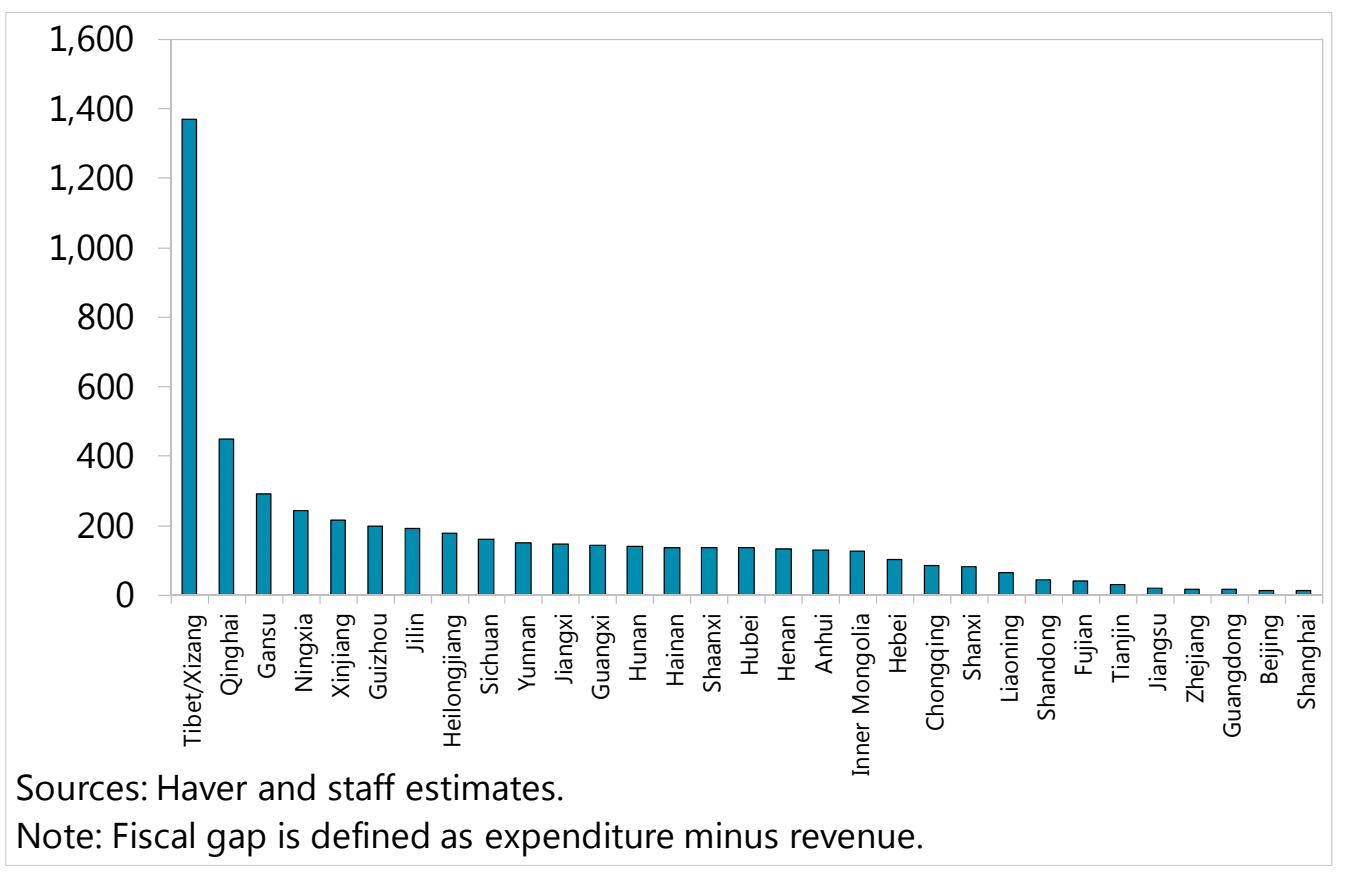

Figure 4. Shares of Local Government Revenue/Expenditure in General Government Revenue/Expenditure (In percent, 2010)

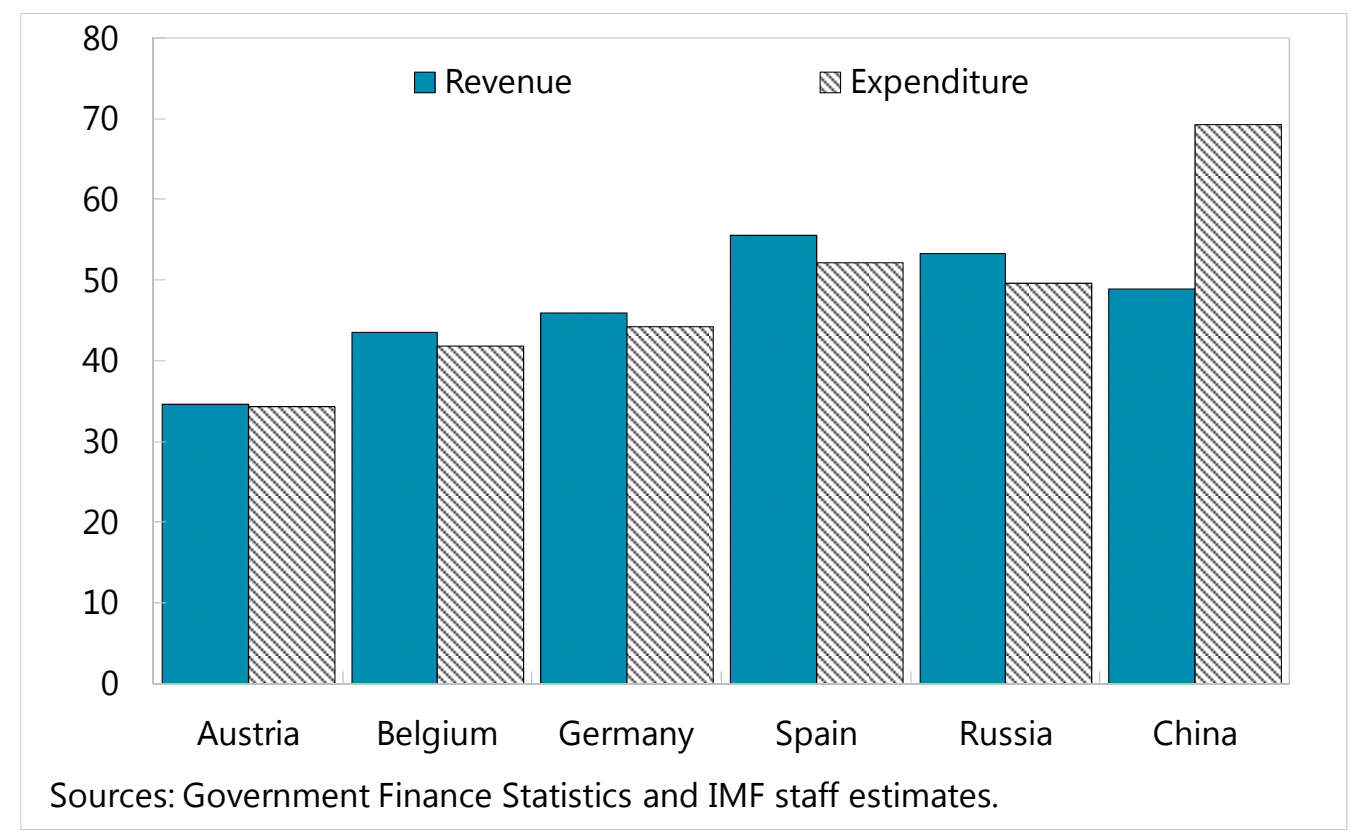


Figure 5. Land Sales Revenue as a Share of Local Government Revenue

(In percent, 2009)

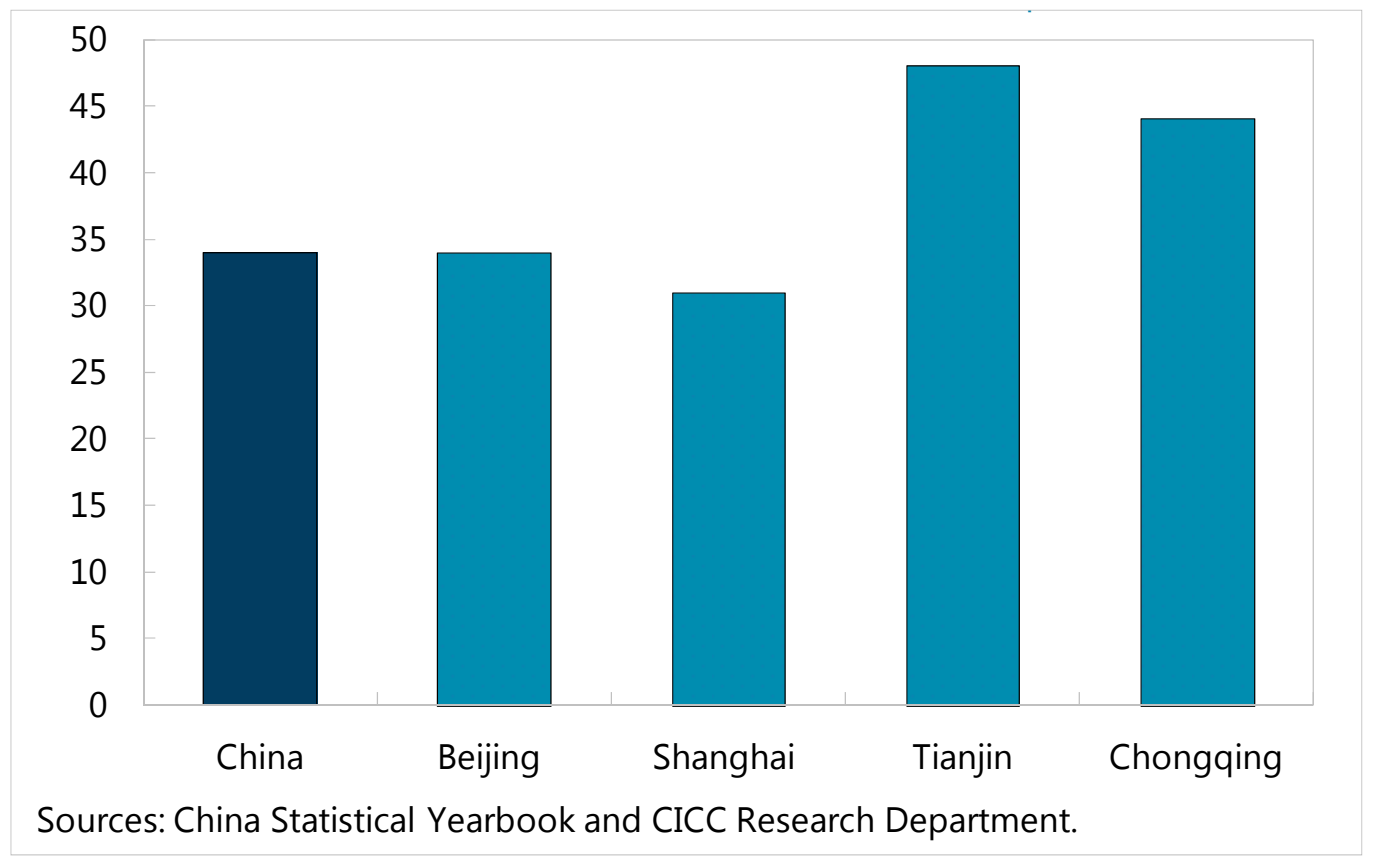

12. The mismatch has been exacerbated by a fiscal stimulus package introduced by the central government to counter the 2008-09 global financial crisis. With investment as the key engine for domestic growth (49 percent contribution to GDP in 2011) - the highest among G20 countries (Figure 6) - and the availability of cheap credit (subsidized by depositors), the central government introduced a fiscal stimulus package (RMB 4 trillion) in late 2008 to shield the domestic economy and employment from external shocks. However, it only contributed RMB 1.18 trillion, with the rest of the package being provided by local governments. The increased fiscal pressures and peer pressure arising from China's unique promotion scheme for officials led local governments to resort to additional financial resources, as the fiscal gap increased in 2009 compared with 2008 (Figure 7). ${ }^{6}$ Since local governments are explicitly prohibited from resorting to market borrowing, they circumvent the Budget Law by setting up entities, such as LGFPs, to access market funding. In this context, LGFPs have become a fortune for the local governments to finance their investment and promote employment.

\footnotetext{
${ }^{6}$ Chinese local government officials are promoted mainly based on their performances in maintaining local economic growth, employment, and social stability. These standards for promotion incentivize the local officials to take whatever available resources (e.g., land and capital) to enhance investment and growth.
} 
Figure 6. Investment to GDP Ratio (In percent, 2011)

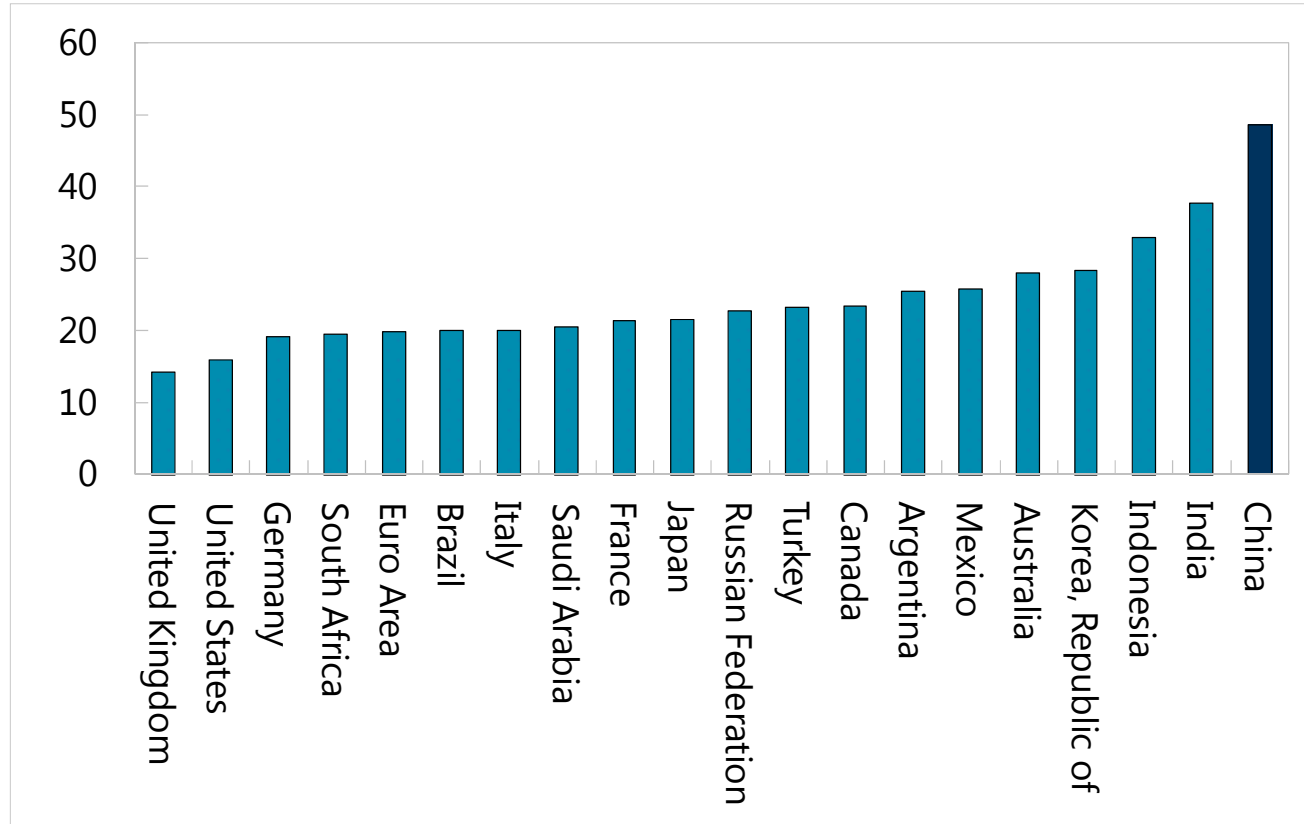

Sources: IMF, IFS; and IMF staff estimates

Figure 7. Transfer-adjusted Expenditure and Revenue Gap by Province (In RMB billion)

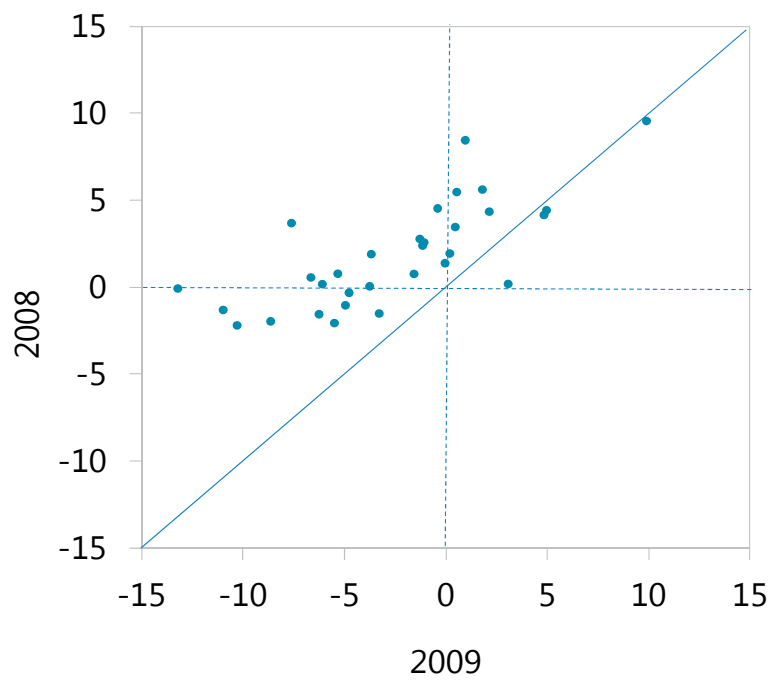

Sources: CEIC; Haver; and IMF staff estimates.

Note: the fiscal gap in most provinces increased in 2009 compared with 2008; thus increasing the pressure for local governments to resort to additional financial resources.

13. Banks have played an important role in providing funding to LGFPs. Among the stock of local government debt (RMB 10.7 trillion as of end-2010, including LGFP debt), RMB 8.5 trillion represents bank loans to local governments. Assuming the same ratio of bank loans to total debt stock as for local governments, of the RMB 4.97 trillion LGFP debt, RMB 4 trillion is in the form of bank loans. This RMB 4 trillion represents about 15 percent of corporate bank loans in the Chinese economy as a whole in 2010. 


\section{Such rapid expansion of lending to LGFPs has revealed banks' internal}

weaknesses. After several years of banking reform, the Chinese banking system has made significant improvement in the areas of risk management and internal controls. However, the fiscal and monetary stimulus has incentivized banks to expand lending to LGFPs:

- $\quad$ First, explicit and implicit guarantees provided by local governments have encouraged banks to grant loans to LGFPs.

- $\quad$ Second, facing strong pressure to increase market share and shareholder value, banks have taken this opportunity provided by the stimulus to expand loans to LGFPs and others.

- $\quad$ Third, the collateral, particularly land, provided by the LGFPs and local governments, has provided banks with a certain degree of comfort when providing loans to LGFPs. The reliance on collateral reflects the fact that banks are not equipped with sufficient tools to price credit risk. Fourth, it cannot be ruled out that local governments' lobbying power may press some conservative banks to lend, as a good relationship with local governments could provide banks with some leeway in conducting local business. This is especially the case for smaller and local banks.

\section{Risks AND VULNERABILITIES}

\section{The rapid development of LGFPs has increasingly made local governments,} banks, and the economy be vulnerable to the volatility of the real estate market. Land owned by local governments constitutes a principal source of LGFPs' capital, future extrabudgetary revenue, and collateral for LGFP borrowing. When times are good, the value of land will increase, enabling LGFPs to extract more loans from a given amount of land. When times turn bad and the value of land falls, cautious banks will demand more collateral. Against this background, one way to meet the demand is to sell land. Such forced sales, particularly into illiquid markets in crisis, would create a vicious circle. In addition, the high reliance of China's economy on construction and real estate would exacerbate the vicious circle (Figure 8). 
Figure 8. Share of Construction and Real Estate in GDP (In percent, 2011)

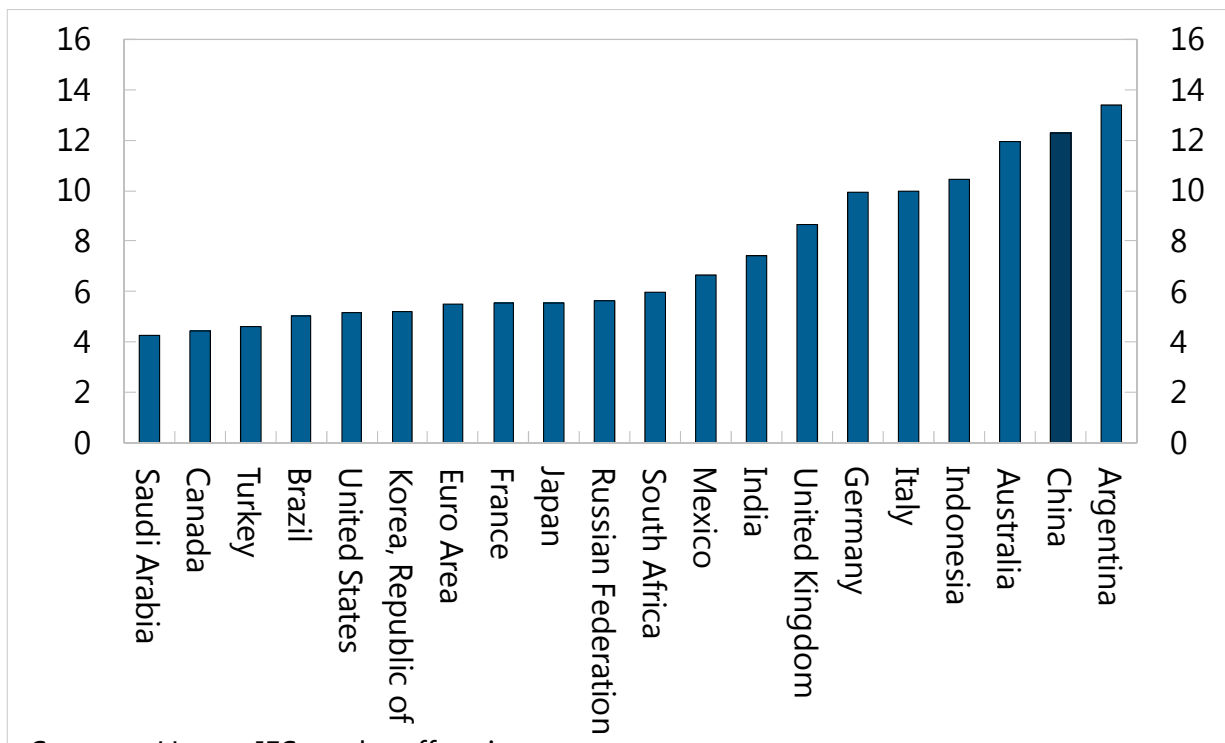

Sources: Haver, IFS, and staff estimates.

\section{A. Local Government}

16. The debt burden for local governments is significant. The NAO report points out that the overall scale of local government debt is large, with over half being related to LGFPs, and debt repayment pressures are substantial for some local governments. The report notes that, in 2009, the highest ratio of debt to financial resources available (e.g., local government fiscal revenue) reached 364.8 percent. Regarding the debt volume, local governments are entirely responsible for RMB 6.7 trillion (or 62.6 percent of the total debt stock of RMB 10.7 trillion). Debt guaranteed by local governments was RMB 2.3 trillion (or 21.8 percent), while the total local government revenue (excluding the receipts from the sale of land lease rights) was RMB 4.1 trillion and income from the central government (i.e., tax rebates and transfer payment) was RMB 3.2 billion in 2010. Among the total local government debts, the LGFP debt amounted to RMB 4.97 trillion, equivalent to two thirds of the sum of local government revenue and transfers from the central government. This suggests that if LGFPs run into financial difficulties, it would not be easy for them to get much financial support from local governments.

17. Much of the local government debt matures in five years (Figure 9). About 24 percent (RMB 2.6 trillion) of the debt was actually due in 2011, representing 60 percent of local government revenue (excluding the receipts from the sale of land lease rights). Debt due in 2016 and thereafter accounts for 30 percent of the total local government debt. These debts represent another 70 percent of local government revenue in 2010 . Obviously, the risk is that local governments may face tremendous debt payment pressure in the coming years with elevating sovereign risk. 
Figure 9. Due Date of Local Government Debt (In RMB billion and percent)

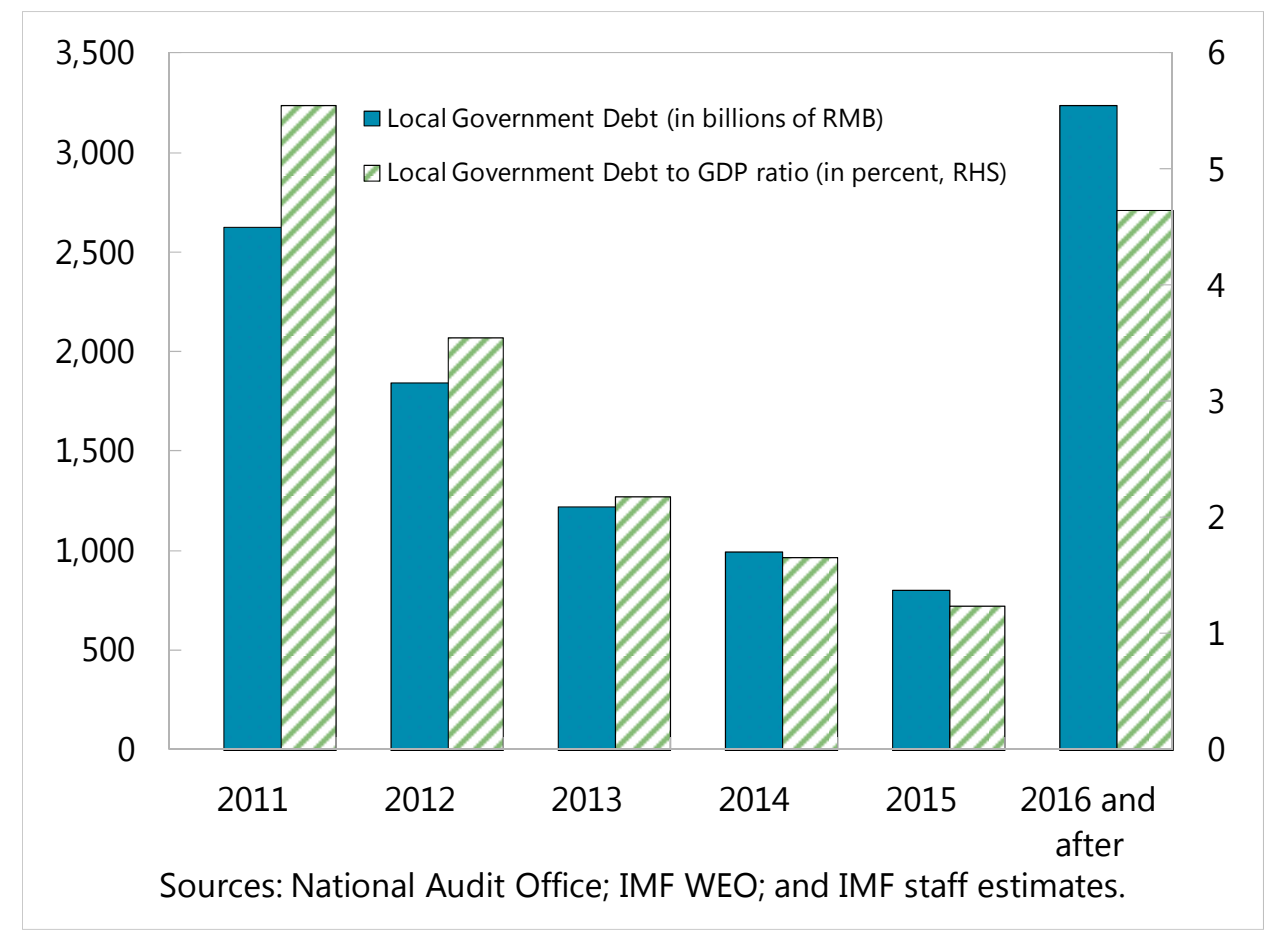

18. Even if the principal of the LGFPs debt is excluded, their interest burden is not negligible. Using the prevailing lending rate of 6.4 percent for medium- and long-term loans, the annual interest payment of RMB 4.97 trillion LGFP loans would be about RMB 320 billion, equivalent to about 6 percent of total revenues of local governments in 2011 (excluding the land sales revenue, which is treated as financing).

19. The distribution of local government debt is uneven. The debt taken by local governments in the eastern region (11 provinces) accounted for about 55 percent of the total debt in 2010; while the middle and western regions accounted for 22 and 23 percent, respectively. For some provinces, the debt burden associated with LGFP loans is several times more than their transfer-adjusted revenue, and will be more if future LGFP debt is counted (Figure 10). ${ }^{7}$ For instance, in the case of Tianjin, the sum of current and future LGFP loans is 11 times the transfer-adjusted revenue in 2010, indicating that it would take Tianjin 11 years to pay back all its the LGFP loans with transfer-adjusted revenue, even if the Tianjin government were to avoid any new expenditures. ${ }^{8}$

\footnotetext{
${ }^{7}$ Current debt includes all existing debt of LICs announced in regulatory filings and bond rating reports. Current debt also includes all lines of credit (after the appropriate discounting) announced after January 1st of 2004 and before January 1st of 2008. Future debt includes all lines of credit announced in and after January 2008. See Shin (2010).

${ }^{8}$ Transfer-adjusted revenue is the sum of local fiscal revenue and the central government transfer amount.
} 
Figure 10. LGFP Loans/Transfer-adjusted Revenue Ratio (In percent, 2010)

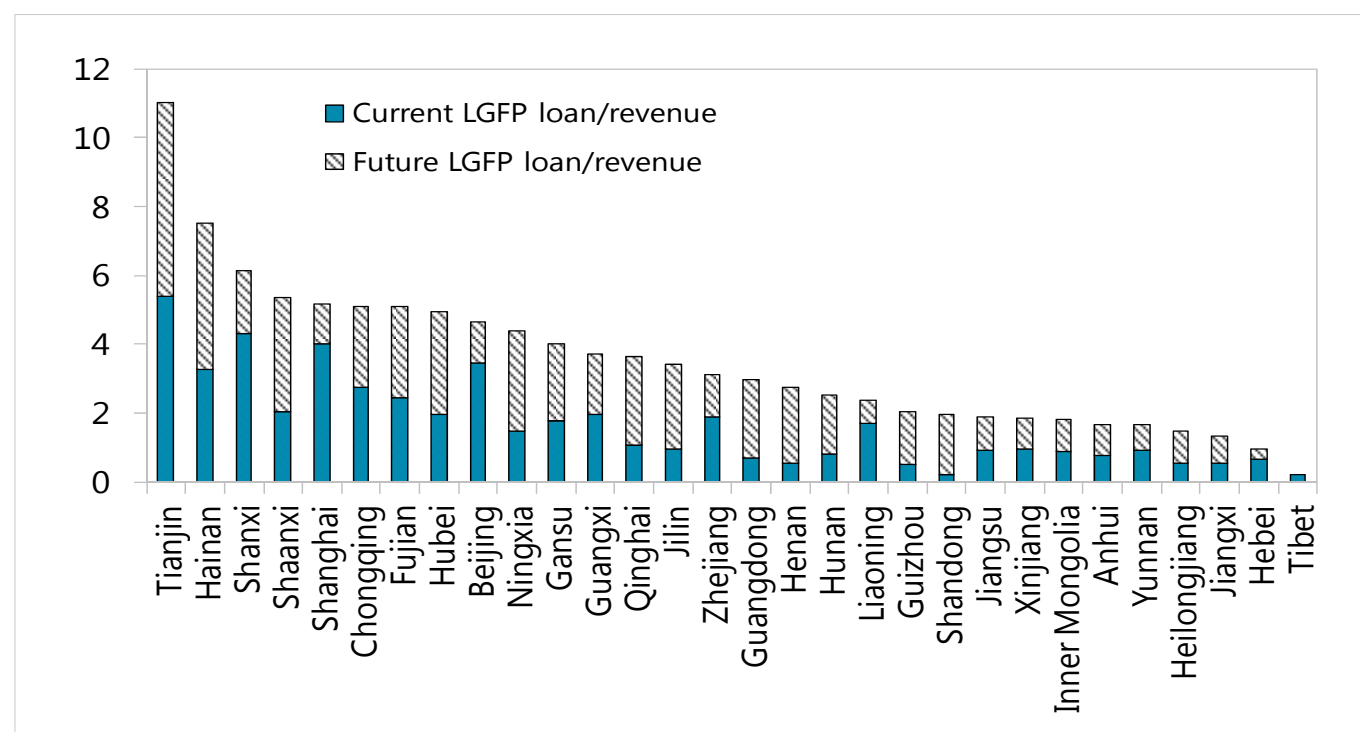

Sources: CEIC; Shin (2010); and IMF staff estimates.

20. The large amount of principal and interest due puts local governments at the mercy of the property markets. The receipts from the sale of land lease rights are the main sources for debt repayment. A potential decline in land value could affect LGFPs' investments in two ways. One is the collateral-damage effect - the decline in land value would inevitably reduce investments. The second is the internal-liquidity effect - with reduced borrowing capacity, a firm has to rely more on internally generated cash to finance its investments. Since many LGFPs are engaged in infrastructure and real estate development, they have scant internal cash flow to finance their investments when the infrastructure projects and real estate market underperform.

\section{B. Banks}

21. A natural negative spillover from LGFPs to banks gives rise to a decline in banks' asset quality. About 15 percent of banks' corporate loans is associated with LGFPs at end-2010. Since LGFPs' loan expansion was mainly targeting large projects with longer maturities, the expansion has led to an increasing amount of new medium- to long-term loans. As a consequence of the increasing share of medium- to long-term loans in new lending, the share of outstanding medium- to long-term loans peaked at 61.2 percent in early 2011 (Figure 11). Such concentration on long-term loans could exacerbate the impact of the economic cycle on banks' asset quality. Though major Chinese banks appear well-positioned to absorb moderate potential losses associated with stand-alone losses from LGFPs, ${ }^{9}$ the impact of the asset quality deterioration of LGFP loans on their NPL ratios is not negligible (Table 1). In addition, the reliance of China's economy on construction and real estate,

\footnotetext{
${ }^{9}$ IMF (2011).
} 
combined with the dominance of land as collateral, makes banks vulnerable to a sharp slowdown in the economy associated with a correction in real estate prices.

Figure 11. Loan Composition in the Banking System (In percent)

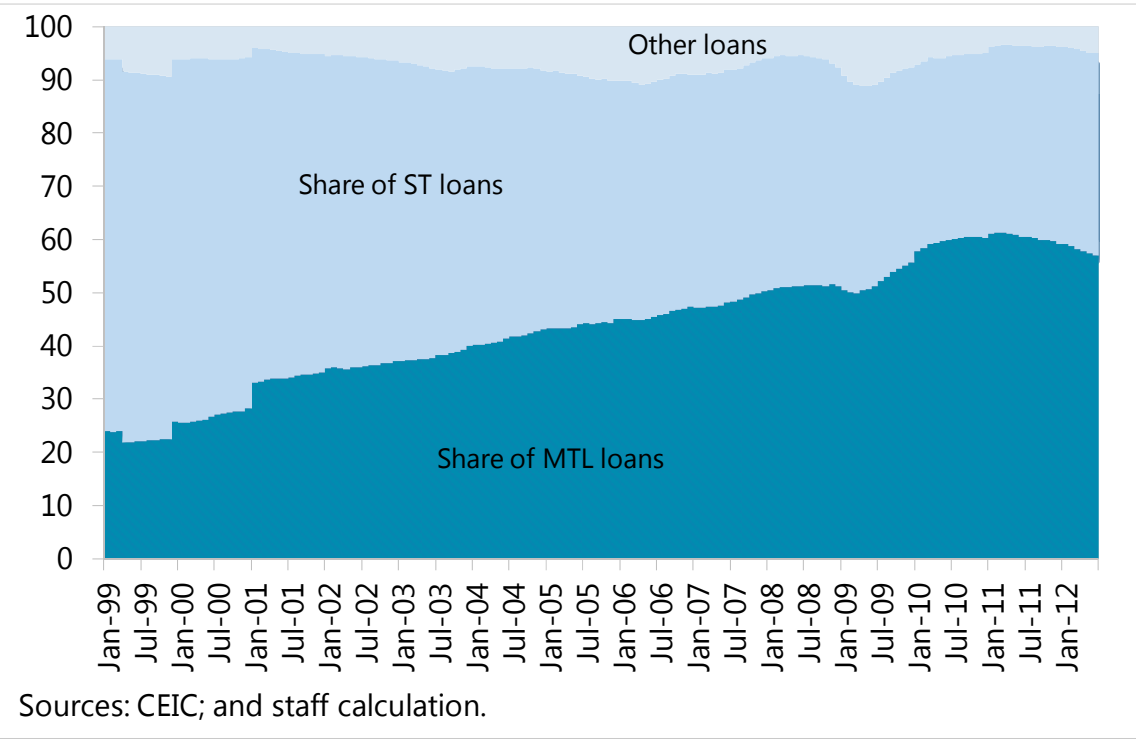

\section{The non-transparency of local governments' fiscal position adds further}

uncertainty. Banks and rating agencies do not have easy access to local governments' overall fiscal position, which includes not only budgeted revenue and expenditure but also extra-budgetary revenue and expenditure. Moreover, the comprehensive financial condition of LGFPs, including their cross-guarantees and subsidiaries, may not even be available to their owners. This lack of transparency prevents banks and rating agencies from pricing credit risk properly and prevents local governments from managing related risks prudently.

Table 1. Chinese Banks' Exposures to LGFPs and Potential Incremental Gross NPL Ratios (2011)

\begin{tabular}{lcccccc}
\hline & & & \multicolumn{2}{c}{ Analysis } \\
\hline & $\begin{array}{c}\text { Gross NPL } \\
\text { ratio (end- } \\
\text { 2011), [A] }\end{array}$ & $\begin{array}{c}\text { Total loans } \\
\text { (RMB million) }\end{array}$ & $\begin{array}{c}\text { LGFP loans } \\
\text { (RMB million) }\end{array}$ & $\begin{array}{c}\text { Share of } \\
\text { LGFP loans }\end{array}$ & $\begin{array}{c}\text { Incremental gross } \\
\text { NPL ratio assuming } \\
35 \% \text { of LGFP loans } \\
\text { become NPLs, [B] }\end{array}$ & $\begin{array}{c}\text { Potential gross NPL } \\
\text { ratio if LGFP loans } \\
\text { become NPLs, [A]+[B] }\end{array}$ \\
\hline ICBC & $1.3 \%$ & $7,943,456$ & 510,000 & $6.4 \%$ & $2.2 \%$ & $3.5 \%$ \\
CCB & $1.4 \%$ & $6,496,411$ & 284,000 & $4.4 \%$ & $1.5 \%$ & $2.9 \%$ \\
BOC & $1.3 \%$ & $6,342,814$ & 380,000 & $6.0 \%$ & $2.1 \%$ & $3.4 \%$ \\
Agricultural Bank & $2.2 \%$ & $5,628,705$ & 390,000 & $6.9 \%$ & $2.4 \%$ & $4.6 \%$ \\
China Development Bank & $0.4 \%$ & $5,525,872$ & $3,683,915$ & $66.7 \%$ & $23.3 \%$ & $23.7 \%$ \\
\hline
\end{tabular}

Sources: Bank annual reports; J.P. Morgan (2011); and Staff estimates.

\section{Sovereign Risk}

23. In the worst case scenario, LGFPs may create potential contagion between the financial sector and the sovereign due to the close linkages between the public sector and banks. The losses in LGFPs could trigger a central government bailout of either local governments or banks. An abrupt increase in government debt and a worsening of the 
government's creditworthiness could generate a loss of confidence in banks given the implicit government support for major banks in China. Though the central government currently has sufficient resources to bail out LGFPs, it may face tough resource constraints to address future financial risks if there is another similar expansion. In addition, it has substantial contingent liabilities (Table 2). This cycle of credit expansion, credit losses, and government bailout would intensify the moral hazard problem and eventually increase China's sovereign risk.

Table 2. Sovereign Balance Sheet of China (2010)

\begin{tabular}{|c|c|c|c|c|c|}
\hline Assets & $\begin{array}{l}\text { In trillions } \\
\text { of RMB }\end{array}$ & $\begin{array}{l}\text { In percent } \\
\text { of GDP }\end{array}$ & $\begin{array}{l}\text { Liabilities and net worth of the } \\
\text { government }\end{array}$ & $\begin{array}{l}\text { In trillions } \\
\text { of RMB }\end{array}$ & $\begin{array}{l}\text { In percent } \\
\text { of GDP }\end{array}$ \\
\hline Deposits of government at central bank & 2.4 & 6.0 & Domestic debts of central government & 6.7 & 16.7 \\
\hline Reserve assets & 19.7 & 49.1 & Sovereign external debts & 2.3 & 5.7 \\
\hline Land assets & 44.3 & 110.3 & $\begin{array}{l}\text { Local government's debts (excluding } \\
\text { LGFPs) }\end{array}$ & 5.7 & 14.2 \\
\hline State-owned assets in administrative & 7.8 & 19.4 & Debts from LGFPs & 5.0 & 12.4 \\
\hline $\begin{array}{l}\text { State-owned assets in nonfinancial } \\
\text { sector }\end{array}$ & 59.1 & 147.2 & $\begin{array}{l}\text { Nonfinancial state-owned enterprises' } \\
\text { debts (excluding LGFPs) }\end{array}$ & 35.6 & 88.7 \\
\hline \multirow[t]{3}{*}{ State-owned assets in financial sector } & 8.2 & 20.4 & Policy banks' debts & 5.2 & 13.0 \\
\hline & & & Non-performing loans (NPLs) & 0.4 & 1.0 \\
\hline & & & Contingent liabilities due to NPLs & 4.2 & 10.5 \\
\hline State-owned assets in social security & 0.8 & 2.0 & Implicit pension debts & 3.5 & 8.7 \\
\hline \multirow[t]{2}{*}{ Total assets } & 142.3 & 354.4 & Total liabilities & 68.6 & 170.8 \\
\hline & & & Net worth of the government & 69.6 & 173.3 \\
\hline
\end{tabular}

Sources: Li and Zhang (2012); and NAO.

24. In the medium term, the vanishing role of LGFPs, underpinned by the authorities' continued monitoring and curbing of their development, along with the declining land sales revenue, may trigger more sovereign risk. An international comparison shows that the deficits to GDP ratios in some provinces were even higher than the deficits to GDP ratio in several high fiscal deficit countries (Figure 12). In the past, these fiscal financing gaps in local governments have been largely covered by the financing from LGFP loans and the land sales revenue. For instance, during 1998 and 2011, the accumulated gaps between local fiscal revenues and expenditures amounted to RMB 18 trillion. Correspondingly, the land sales revenue rose from RMB16 billion in 1998 to RMB 3.2 trillion in 2011, with the accumulated annual land sales revenue during 1998 and 2011 amounting to RMB 13 trillion (see detailed discussion in section V.C). By adding the LGFPs loans of around RMB 4.97 trillion, the total revenue roughly covered the gaps between the local fiscal revenue and expenditure. 
Figure 12. A Comparison of Deficits to GDP Ratios between Chinese Provinces and Several High Fiscal Deficit Countries (2011)

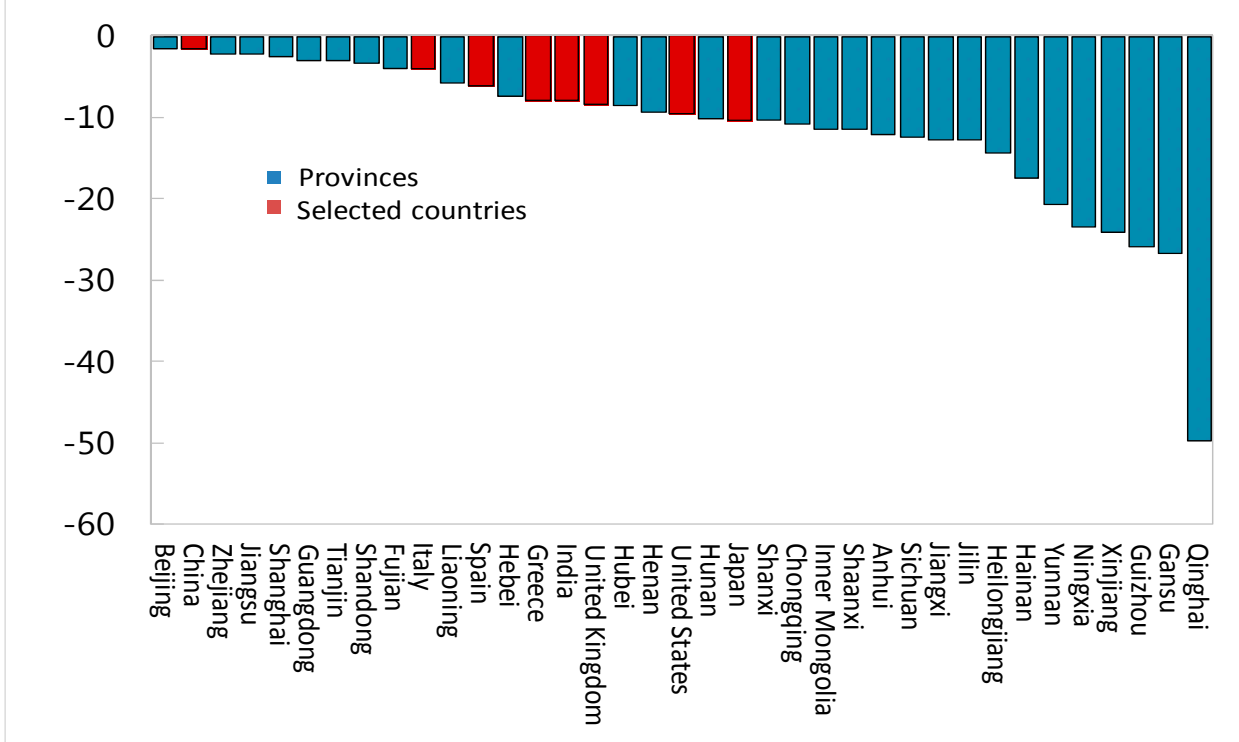

Note: The data on Chinese provinces is the ratio of fiscal balance (without adjusting for fiscal transfers) to local GDP. The data for countries is the ratio of fiscal balance to GDP.

Sources: CEIC; IMF; and IMF Staff estimates.

25. From a broad perspective, rapid credit expansion to LGFPs further distorts China's economic structure. The procyclical behavior of LGFPs, along with the rapid credit expansion, could result in excessive leverage and risk taking in the upswing, and, as a consequence, excessive deleveraging in the downswing, thereby creating excessive volatility with dire consequences for financial stability and the real economy. Credit expansion to LGFPs could crowd out lending to the private sector, lead to the misallocation of capital, increase the reliance of the economy on investment, and exacerbate economic imbalances. Although credit expansion has stabilized growth in the short term, the economic sustainability may be jeopardized.

\section{Policy Suggestions}

26. The existence of the mechanism for local governments to borrow has been acknowledged since the formation of LGFPs in 2005. Although the role of LGFPs has been viewed with a degree of suspicion in the recent credit expansion, it should be acknowledged that LGFPs serve useful purposes. LGFPs have been regarded as effective in financing large projects, such as social welfare programs and infrastructure projects. Their role in promoting economic growth, especially during the global financial crisis, has been acknowledged by the Chinese authorities. ${ }^{10}$

27. The large increase in LGFP borrowing has led the authorities to strengthen the supervision of lending to LGFPs. At the end of 2009, the CBRC, People's Bank of China

\footnotetext{
${ }^{10}$ See the CBRC 2009 annual report.
} 
(PBC), and Ministry of Finance (MOF) conducted a survey to assess the indebtedness of local governments. As an initial requirement, banks had to set standards and classify LGFP loans by September 30, 2010. However, the strongest message came from the State Council in June 2010, when it issued measures to strengthen the management of LGFPs. Four main policy measures were launched: 1) assess, verify, and properly manage the debts assumed by the LGFPs; 2) classify and regulate the function and operation of existing LGFPs; 3) strengthen the supervision of LGFPs' lending activities, as well as banks' and other financial institutions' lending practices to LGFPs; and 4) prohibit local governments from guaranteeing LGFP debts. As a follow-up, the MOF, National Development and Reform Commission, PBC, and CBRC jointly issued detailed implementation rules. In April 2013, the CBRC distributed guidance to further strengthen the supervision of loans to LGFPs with key requirements including: 1) banks' stock of LGFP loans should not exceed the existing stock at end-2012; 2) banks can grant new loans only to LGFPs with a cash flow coverage ratio above 100 percent, a liability-to-total asset ratio below 80 percent, and collateral that complies with regulations.

28. These measures are a move in the right direction. For instance, the measure to assess the scale of LGFPs' indebtedness has helped the authorities to understand the potential contingent liabilities from the LGFPs. The measure to classify LGFPs into several categories and clarify their functions has helped in determining any remedial actions to be taken. It is also useful to make the funding more transparent. The aim of the other two measuresstrengthening the supervision of LGFPs' borrowing activities and prohibiting unauthorized guarantees for LGFP debt-is to control and monitor new LGFP-related lending activities.

29. However, more work needs to be done to address the fundamental reasons for the proliferation of LGFP debts to prevent similar problems from occurring again. Fiscal, monetary, and financial policies should work together to reduce the vulnerability of local governments to a deterioration in the financial condition of LGFPs and, looking forward, to avoid repetition of the proliferation of LGFP debts. The mismatches between revenue and expenditure at the local government level should be fully acknowledged and addressed. A system with sufficient fiscal transfers from the central government to local governments could be helpful in reducing the revenue-expenditure mismatches in the local governments. In addition, it is necessary to establish a comprehensive framework to regulate and supervise local government budgets and its financing. Moreover, it is important to ensure that resources obtained from the sale of land use rights are sustainable, which requires a comprehensive plan for land capitalization. Finally, it is beneficial to encourage the development of a local government bond market to help diversify local governments' financing sources and promote capital market development.

\section{A. Addressing the Fiscal Revenue and Expenditure Mismatches}

\section{Unfunded local government responsibilities should be funded through the}

transfer system. The transfer system should be less ad hoc in nature, targeting greater 
transparency, predictability, and reliability in central and local fiscal relations. Given the regional growth inequality, transfers should play a role so that less developed areas will have enough funding for growth. The expenditure responsibilities of local governments should be clarified.

\section{China should start levying property taxes to reduce reliance on land sales}

revenue. Local governments in many countries rely on property taxation and, in turn, local communities benefit from the range of services funded by the property taxes (Table 3 ). In China, property tax could provide local governments with resources for capital expenditure and also curb speculation in the housing market. Property taxes will help the local governments to have more stable revenue sources so that they can reduce their dependence on land sales revenue that is highly cyclical to economic activity. The good news is that pilot programs have been carried out in Shanghai and Chongqing, which permit these two municipal governments to collect property taxes on newly purchased second homes or luxury residential property.

Table 3. Revenue Categories: Property Taxes (In percent of GDP)

\begin{tabular}{lcc}
\hline Country & Year & Taxes on Property \\
\hline Argentina & 2004 & $2.64^{1 /}$ \\
Australia & 2008 & $2.50^{1 /}$ \\
Canada & 2008 & 2.99 \\
China & 2007 & $1.85^{1 /}$ \\
France & 2008 & $4.37^{1 /}$ \\
Germany & 2008 & $0.81^{1 /}$ \\
Italy & 2008 & $0.67^{1 /}$ \\
Japan & 2006 & 0.3 \\
Russia federation & 2008 & 1.05 \\
South Africa & 2008 & $1.37^{1,2 /}$ \\
United Kingdom & 2008 & 5.48 \\
United States & 2008 & 3.13 \\
\hline Source: IMF Government Finance Statistics, 2009. \\
1/ Data are provisional. \\
2/ A break in the comparability of data, i.e., data are not \\
comparable with earlier years.
\end{tabular}

32. Several steps should be involved in the process of taxing property. They include identifying property, assessing property value, setting the tax rates, issuing tax bills, and collecting taxes (see Dillinger (1992)). Criteria for good property tax schemes include fairness to both tax payers and benefit receivers, no distortion to economic behavior, accountability to tax payers, and ease of administration. 


\title{
B. Establishing a Comprehensive Framework to Regulate and Supervise Local Government Budget and Financing
}

\begin{abstract}
33. Following Ter-Minassian (1997), there are four broad categories of regulation and supervision on local government borrowing. They are 1) market-based discipline, which means that countries rely on capital markets to control local government borrowing; 2) a cooperative arrangement, through which a negotiation process between the central and local government designs local government borrowing limits; 3) rule-based controls, which means the central government controls local government borrowing by imposing quantitative rules or qualitative constraints; and 4) administrative constraints, through which the central government retains the power for exercising direct control over local government borrowing (see Annex).
\end{abstract}

34. The rule-based approach to manage local government borrowing may be the most suitable approach in the case of China. First, given China's centralized political system, the cooperative arrangement will not work. Second, the administrative approach limits the efficiency of decentralizing public spending and encourages moral hazard brought about by explicit and implicit guarantees. Third, while a select group of financially sound Chinese local governments could take the market-based approach on a trial basis; several conditions have to be met to maximize the benefits and minimize the weaknesses of the rulebased approach and prepare some local governments for the market-based approach (see annex).

\section{Providing fiscal transparency and a complete picture of local governments' finances}

\section{In order to control, monitor, and supervise local governments' financing} activities, it is essential to have a complete picture of their finances. The complete picture should reflect official budget items, extra-budgetary resources, local SOEs or even private enterprises that carry out local governments' functions, and other contingent liabilities and guarantees of local governments. The complete picture should be made public to enable market players to assess local governments' fiscal situation. While the State Council's request to assess LGFP debts is a step in the right direction, the scope could be usefully expanded to include other types of SOEs, private enterprises that transfer some risk away from local governments, and other types of government liabilities, such as payment arrears, on-lending, and social security.

\section{Some local SOEs can be more independent than others, but all should be} monitored by all levels of government. Local SOEs that are commercially run, are in a sound financial condition, and have a good governance structure and managerial independence, should be kept at arm's length from local governments. On the other hand, those SOEs that are not commercially run and need support from local governments should be incorporated into the local governments' budget. 
37. Some private enterprises and joint ventures that are involved in carrying out public functions, particularly infrastructure, should also be included in local governments' finances. If there is risk transfer to the private sector, their activities should be treated as public investments. In the case of China, private enterprises are often involved in conducting public investment, and the usual format is through build-transfer (BT) and buildoperate-transfer (BOT) contracts between private enterprises and the local governments. Private enterprises use these contracts to secure loans from commercial banks; therefore, the risk transferred to the private sector should be closely monitored to ensure that the transfer genuinely takes place, and their activities should be included in local governments' finances.

38. Extra-budgetary resources should be incorporated in the formal budget as well. Aware that local governments have extra-budgetary resources, the central government has an incentive to decentralize the economic stimulus to local governments without providing matching resources. Currently, the single biggest extra-budgetary resource for local governments is the land sales revenue from selling land use rights. ${ }^{11}$ This revenue resource should be incorporated in the official budgets.

39. The complete picture of local governments' finances should be systematized by the central government and made transparent to the market. The central government could create a systematic and comprehensive information system to enable it to supervise the activities of local governments. The key indicators of the financial health of local governments could be made public to allow the financial institutions and markets to control local governments' borrowing activities.

\section{Strengthening the Framework for Managing Direct and Contingent Liabilities at the Local Level}

\section{A centralized management system would enhance the capacity of local}

governments to manage risk. A debt management vacuum and risky debt management practices increase the vulnerability of an economy to economic and financial shocks. The poor structure of debt in terms of mismatches of revenue and payment, maturity, and large and unfunded contingent liabilities are important factors that can lead to or amplify a crisis. In case the local governments do not have the capacity to set up a framework to manage their liabilities, the central government could set up a centralized management system to manage the risks to which the central government and individual local governments are exposed.

\section{Setting Up a Credible Ex-Post Mechanism for Resolving Local Governments' Insolvency}

\section{A credible ex-post mechanism would support the effectiveness of ex-ante} regulations. A history of bailouts, the existence of gap-filling transfer mechanisms, and the

\footnotetext{
${ }^{11}$ Land sales revenue for China's local governments rose more than 60 percent in 2009 as the country's property market surged. Local governments generated RMB 1.59 trillion (\$233 billion) from the sale of 209,000 hectares of land in 2009. Of that, 103,000 hectares were sold to real estate developers, up 36.7 percent year on year. (The Ministry of Land Resource and China Daily, Feb 2, 2010).
} 
lack of a credible system of sanctions and penalties create moral hazard, strengthen perverse incentives, and encourage local governments' fiscal irresponsibility and imprudent lending by financial institutions. Therefore, a credible ex-post mechanism is needed to deter the irresponsible behavior of both local governments and lenders. Such a mechanism would enhance the effectiveness of ex-ante regulations.

42. A conditional bailout principle could be more applicable to China. International experiences indicate that the challenges involved in implementation of a no-bailout principle in reality make a conditional bailout more realistic. Although the no-bailout principle may be optimal in the long run, it is difficult for the central government to commit to it. ${ }^{12}$ Persson and Tabellini (1996) and Brodignon, Manasse, and Tabellini (2001) have demonstrated that in order to maximize a federation's social welfare, it is beneficial for the federal government to bail out a financially distressed region. Since China is a country without an established credit culture, the perception is that there will be a bailout if a local government has financial difficulties. Therefore, the credibility of a no-bailout commitment is doubtful. Hence, the principle of a conditional bailout could be applied..$^{13}$

43. Burden sharing with lenders would help prevent moral hazard by lenders. Local governments' ownership of LGFPs has been factored into commercial banks' lending decisions. In assessing the risk of lending operations, banks often take into account the financial health of the related local government. Both activities implicitly assume that local governments will bear responsibility for the related liabilities if LGFPs are not able to repay the loans. This assumption is likely to lead to imprudent lending activities by commercial banks; therefore, requiring commercial banks to share the burden of the consequences of defaults is likely to help reduce the moral hazard.

\section{In the case of China, the central government has to share part of the} responsibility for local government borrowing that occurred during this stimulus. In the RMB 4 trillion fiscal stimulus package promulgated in early 2008, only RMB 1.18 trillion was planned to come from central government and the remainder would from other sources, including funding raised by local governments. The overall budget deficit increased by only RMB 614 billion. ${ }^{14}$ Except for the RMB 200 billion that the MOF raised on behalf of local governments by issuing bonds, most of the funding needs were met through LGFPs'

\footnotetext{
${ }^{12}$ For instance, in the case of the United States, the no-bailout principle was set up during the first local government default in the 1840s. Federal government resisted the pressure to bail out eleven states and the Territory of Florida that were in serious financial trouble. In the end, eight states and the Territory of Florida defaulted on their debt. States were prompted to write new constitutions to impose new limits on borrowing.

${ }^{13}$ Brazil, a country with a complex structure of fiscal federalism, has experienced three local government debt crises $(1989,1993$, and 1997) since the 1980s. After two rounds of bailing out local government, Brazil adopted a stricter approach in which a bailout is conditioned on local governments' fiscal adjustment. The 2000 Fiscal Responsibility Law consolidated and strengthened the ex-ante regulations on local government borrowing (Lili Liu and Michael Waibel, 2008).

${ }^{14}$ IMF (2010).
} 
borrowing from commercial banks, with guidance to do so by the PBC and CBRC. Therefore, the central government needs to take responsibility for this portion of LGFPs' borrowing. This is the price that the central government should pay for decentralizing the economic stimulus to local governments without providing sufficient resources.

\section{Allowing financially sound local governments to issue bonds that would be priced by the market}

\section{Setting up a municipal bond market would allow creditworthy local} governments to access capital markets. In this market, creditworthy local governments could be encouraged to raise financing for long-term projects and the prices of their bond issues would be determined by the market. This channel could also provide an additional investment channel. A pilot project has been undertaken in cities such as Guangdong, Shanghai, Shenzhen, and Zhejiang. To reduce moral hazard arising from implicit central government guarantees, the central government should make clear that it will not provide any guarantees on bonds issued by local governments.

\section{Ensuring the Sustainability of Land Capitalization Process}

46. China still has a large amount of land available for construction (Figure 13). China's available construction land can provide 100 square meters per person, even if only urban construction land is used (CICC, 2010). If such a large amount of land can be capitalized in a well-managed and efficient way, local governments may obtain more sustainable resources through this land capitalization process.

Figure 13. Composition of Urban and Rural Housing and Construction Land (10 thousand square kilometers)

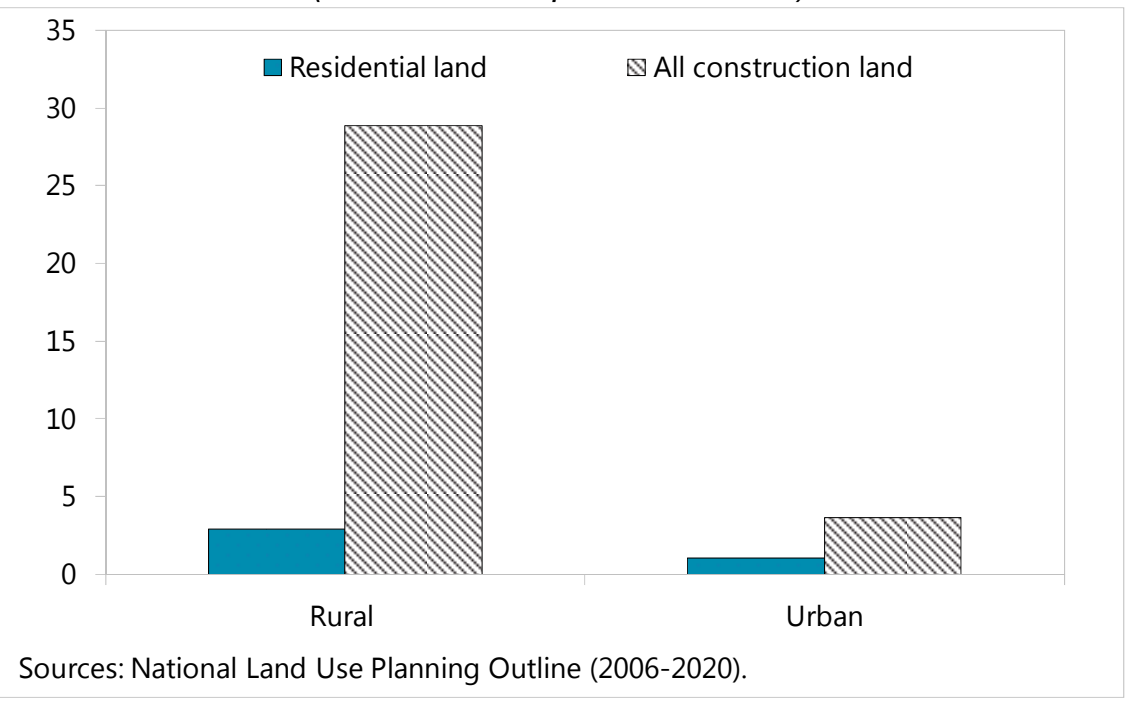


Figure 14. Reliance on Land Sale by Region

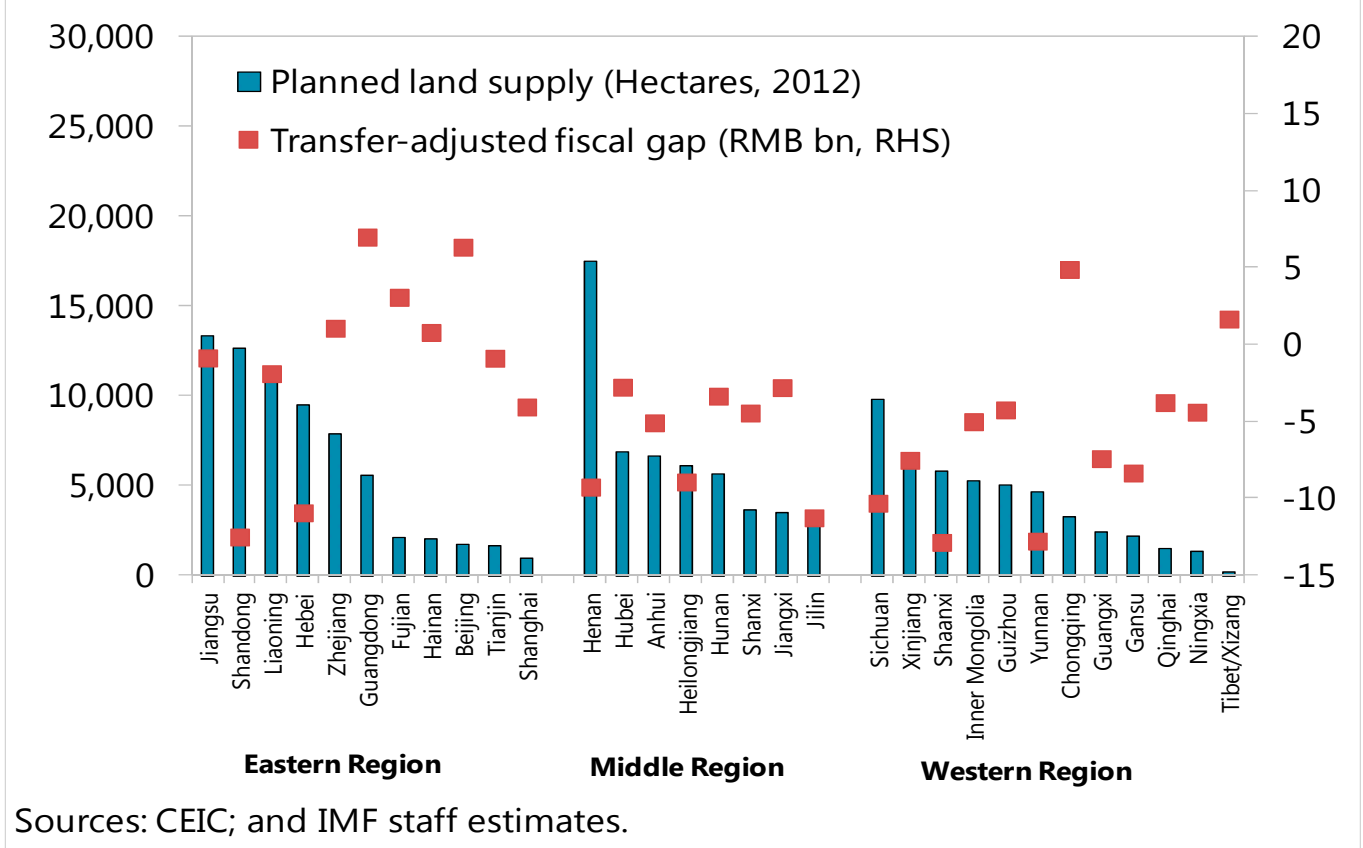

47. The current land management system has a strong link with fiscal gap and housing prices. On the one hand, the less the land supply is, the less the amount of land sales is, and therefore the higher the fiscal gap could be. This can be shown by a negative relationship between the land supply and fiscal gap (Figure 14). On the other hand, local governments and real estate developers also have strong incentives to hold back the release of new land to wait for the benefits from land price increases. The more restraints that are placed on land supply, the higher likelihood for housing prices to increase. This conflicting incentive on land supply may create confusion and hence deter the planned completion of housing construction.

48. The completion rate of the land supply plan is low. In 2009, at the national level, 55 percent of the planned land supply was completed. That is, only 55 percent of the planned land supply was finished for construction. This rate varies among cities. For example, in Chongqing, the completion rate in 2009 was 81 percent, while the rate in Shanghai was 48 percent.

\section{Land capitalization-collecting capital through selling land and investing the} proceeds-may come to end in ten years, if the current approach of heavy reliance on land sales revenue continues. The supply of available land that can be sold by local governments will eventually run out. By making a few assumptions-the total land value was RMB 44.3 trillion at 2010 (Li, 2012), land prices increase at the same speed as in 2010, and land sales revenue grows at the speed of the past couple of years-a rough estimate shows that the land may be fully sold by around 2021 (Figure 15). The end of the land capitalization process would not only mean that the local fiscal gaps could no longer be met though 
collecting land sales revenue, but would also suggest a sharp slowdown in local investments and economic growth, as well as rising non-performing loans in the bank sector.

50. Managing the amount and speed of available land supply in a more transparent and sustainable way would help provide local governments with sustainable resources. Since the limited land supply is positively correlated with future house price increases, some local governments may slow down land supply to wait for more house price increases, and thus more land sales revenue. It would therefore be useful for the central and local governments to take steps to manage the amount and speed of land supply to meet the rational demand for land.

Figure 15. Expected Decline in Available Land and Land Sales Revenue

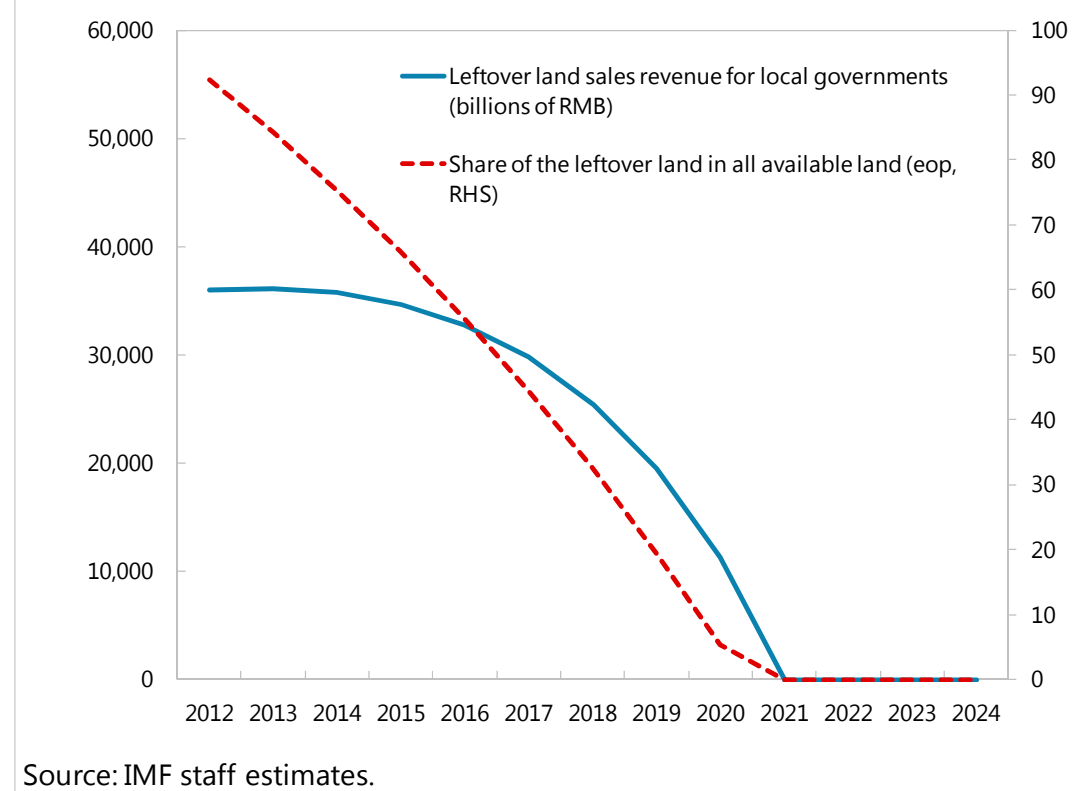

\section{Developing Local Government Bonds into Safe Assets}

51. Safe assets are used as a reliable store of value to preserve capital in portfolio construction. They are a key source of liquid, stable collateral in private and central bank repurchase (repo) agreements and in derivatives markets, acting as the "lubricant" or substitute for trust in financial transactions (IMF, 2012). China could benefit from a larger supply of domestically-produced safe assets.

52. Developing the central and local governments' bonds into a category of domestic or even global safe assets can help the Chinese authorities address the challenges associated with local governments in the following ways.

- $\quad$ Creating a sustainable financing channel to gain more benefit from financial globalization. Besides the RMB 1.1 trillion of central government bonds that could be first developed into safe assets, the Chinese local governments could provide another $\$ 3$ trillion (about RMB 20 trillion) in bonds that would be issued to domestic and 
global investors, helping to alleviate what seems to be a shortage of safe assets since the European sovereign crisis began. This sum is more than the accumulated land sales revenue, and roughly equal to the accumulated financing gaps between local fiscal revenues and expenditures between 1998 and 2011.

- $\quad$ Reducing the financing cost for local governments. An increase in domestic or even global demand for local government bonds would help reduce the financing cost for local governments. Therefore, for instance, a decline of one percentage point in the interest rate for the $\$ 3$ trillion local government bonds would save RMB 200 billion in interest expenditure for the local governments.

- $\quad$ Ensuring the sustainability of the land capitalization process. A standardized review alongside the issuance of local government bonds will greatly improve transparency and market discipline in collateralizing and using the land. As a result, the land capitalization process will become more sustainable and provide additional leeway for the central government's fiscal reforms, thereby alleviating potential sovereign risk.

\section{Conclusion}

53. The rapid development LGFPs in the past four years reflects several factors: an economic growth model that is reliant on investment; growing fiscal gaps in local governments; limited financing capacities and instruments at the local government level; the heavy reliance on land sales revenue; and the unconstrained provision of loans driven by the yet-to-be completed commercialization of banks.

54. The risks associated with LGFPs arise mainly from three areas: (i) the credit risk that may result in the inability for banks to collect part of their loans; (ii) the potential fiscal risk in Chinese provinces; and (iii) a future collateral loss related to potential declines in land prices, which may constitute a contagion channel across local governments, the banking sector, the real estate sector, and the central government.

55. Addressing the risks arising from LGFPs and avoiding their realization requires a comprehensive set of policies. This set of policies includes (i) the successful transformation of the economic growth pattern from export- and investment-driven to consumption-driven mode; (ii) matching local fiscal revenue and expenditure; (iii) encouraging qualified local governments to issue bonds; and (iv) managing the amount and speed of the release of land in a more transparent and sustainable way. Such policies are urgently needed to reduce the heavy reliance on land sales to meet local fiscal gaps.

\section{Issuing and promoting local government debt as a category of global safe assets requires more fundamental reforms. Such reforms include:}

- Increasing the depth of China's bond market by encouraging those local governments with robust fiscal revenue and state-owned assets to issue more bonds; 
- Promoting financial market depth by enlarging securitization of the LGFPs' loans and land; and

- Continuing the momentum of exchange rate liberalization and capital account liberalization to facilitate foreign investment in domestic local government bonds.

In sum, LGFPs represent a current risk to China's economy. However, by implementing a comprehensive set of policies, these vehicles could add greatly to China's economic development and financial stability. 


\section{Annex: Four Broad Categories of Regulation and Supervision on Local Government Borrowing}

\section{A. Market-based Discipline}

1. Market-based discipline means that countries rely on capital markets to control local government borrowing. In such cases, the central government does not specify any limits on local government borrowing and accordingly local governments are free to decide the borrowing amount, sources, and uses. The local governments of some countries that adopt this discipline may choose to set self-imposed rules for self-regulation (e.g., Canada, Switzerland, and the United States).

\section{However, Lane (1993) points out that in order for financial markets to impose} effective discipline on local government borrowing, several conditions have to be met. First, markets should be open and free, particularly without regulations that could put local governments in a privileged-borrower position. Second, adequate information on local government debt stock and repayment capacity should be easily accessible to potential lenders. Third, there should be no assumption of a central government bailout. Fourth, local government should have the institutional structure to ensure adequate policy responsiveness to market performance.

\section{B. Cooperative Arrangement}

3. In this category, a negotiation process between the central and local government designs local government borrowing limits. Local governments are actively involved in designing macroeconomic objectives and determining key fiscal parameters including overall fiscal deficit targets, and the main items of revenue and expenditure. Then both parties agree upon specific limits for the financing requirements for individual local governments. In Australia, a loan council was set up for coordinating the fiscal policies and borrowing decisions of Australian states and the Commonwealth as a whole.

\section{The advantages of such an approach are clear as are its weaknesses. By} encouraging coordination and dialog among different levels of government, it has the potential to ensure the coordination of macroeconomic policy and raise the awareness of local governments about the macroeconomic implications of their budgetary choices. But if implemented poorly, it may soften the budgetary constraints on local governments, undermine the leadership of the central government, promote "bargaining" on intergovernmental transfers, and weaken coordination.

\section{Rule-based Controls}

5. Through this approach, the central government controls local government borrowing by imposing quantitative rules or qualitative constraints. Quantitative rules may take the form of restrictions on the overall debt amount (e.g., Hungary), expenditure 
ceilings (e.g., Belgium, Germany), indicators of debt-servicing capacity (e.g., Brazil, Colombia, Korea, India, Japan, Spain), budget deficits (e.g., Austria, Spain), and operating budget deficits (e.g., Norway). Qualitative constraints may take the form of limiting the types of borrowing, such as "golden rules" which limit borrowing to investment purposes only (e.g., Brazil, Colombia, Germany, Mexico, Peru, the Russian Federation, and the United Kingdom); restricting access to some financing sources, such as restricting access to external borrowing (e.g., Mexico); or the requirement to establish a medium-term fiscal framework and a transparent budgetary process (e.g., Brazil, Colombia, and Peru). ${ }^{15}$

\section{Rule-based controls are attractive but are likely to promote evasive behavior.} They have the advantage of being clear, transparent, and impartial as well as avoiding extensive negotiations between central and local governments. However, the effectiveness of this approach depends on the balance between ensuring compliance and preserving flexibility. The lack of flexibility could ultimately promote evasive behavior and practices; while flexible rules with escape clauses lack credibility and encourage rule circumvention.

7. Evasive behavior could take several forms. Restrictions on borrowing for current expenditure in favor of borrowing for capital expenditure (i.e., golden rules) could lead to classifying current expenditure as capital expenditure. If restrictions only apply to budget items, local government will create off-balance sheet items and SOEs with extra-budgetary statutes to circumvent the restrictions. These SOEs could be used to borrow money for purposes that should be funded by the local government budgets. Accumulating "hidden" off-budget debts or using sale-and-lease-back operations are also ways to circumvent borrowing limits.

\section{Administrative Approach}

8. Among the four approaches, the administrative approach is the strictest way to control local government borrowing. The central government retains the power for exercising direct control over local government borrowing. It may take the form of setting the annual or semiannual individual local government debt ceiling (Lithuania), reviewing and authorizing individual borrowing operations (India and Bolivia), or centralizing all government borrowing with on-lending to local governments (Latvia and Indonesia).

9. Such an approach is often seen in constitutionally centralized countries. Though it ensures some level of coordination of the borrowing activities for a nation as a whole, it introduces implicit or explicit guarantees of local government debt. In addition, the effectiveness of such an approach could be limited by the fact that the central government may have imperfect information on local government projects, and so projects with low quality or high risk may be selected.

\footnotetext{
${ }^{15}$ Singh and Plekhanov (2005) and Liu and Waibel (2008).
} 


\section{REFERENCES}

Bordignon, M., P. Manasse, and G. Tabellini, 2001, "Optimal Regional Redistribution under Asymmetric Information,” American Economic Review, Vol. 91 (3), pp. 709-23.

China International Capital and Corporation Limited, 2010, "The Reasons for the Shortage of Land," CICC Research (May).

China Banking Regulatory Commission, 2009, Annual Report.

Dillinger, William, 1992, Urban Property Tax Reform Guidelines and Recommendations. Washington, D.C.: World Bank, Urban Management Program.

International Monetary Fund, 2010, People's Republic of China: 2010 Article IV Consultation, Staff Report; Staff Statement; Public Information Notice on the Executive Board Discussion, IMF Country Report No. 10/238 (Washington: International Monetary Fund).

International Monetary Fund, 2011, People's Republic of China: Financial System Stability Assessment, IMF Country Report. No. 11/321 (Washington: International Monetary Fund).

International Monetary Fund (IMF), 2012, "Safe Assets: Financial System Cornerstone?” Chapter 3 in Global Financial Stability Report, World Economic and Financial Surveys (Washington, April).

J.P. Morgan, 2011, "China Banks, Misleading Reuters Report Distorted Positive Developments on LGFV Loans,” June 6, 2011.

Lane, Timothy D., 1993, “Market Discipline," Staff Papers, International Monetary Fund, Vol. 40 (March), pp. 53-88.

Li, Yang, and Xiaojing Zhang, 2012, “China’s Sovereign Balance Sheet," Chinese Social Sciences Publishing House, 2012.

Liu, Lili, and Michael Waibel, 2008, "Subnational Insolvency: Cross-Country Experiences and Lessons," World Bank Policy Research Working Paper 4496.

Meng, Yang, 2009, "Banks Need to be Cautious in Lending to Local Government Financing Platforms, " Jin Rong Shi Bao, November 4, 2009, available at http://bank.jrj.com.cn/2009/11/0405026389728.shtml

National Audit Office of the People's Republic of China, 2011, "Report on the Local Government Debt Audit Work," 2011, No. 35, available at http:/www.audit.gov.cn/n1992130/n1992150/n1992500/2752208.html

Persson, Torsten, and Guido Tabellini, 1996, "Federal Fiscal Constitutions: Risk Sharing and Moral Hazard," Econometrica, Vol. 64 (May), pp. 623-46.

Shih, Victor, 2010, "Local Government Debt Big Rock-candy Mountain," China Economic Quarterly, June 2010, pp. 26-32.

Singh, Raju, and Alexander Plekhanov, 2005, "How Should Subnational Government Borrowing be Regulated? Some Cross-Country Empirical Evidence," IMF Working Paper 05/54 (Washington: International Monetary Fund).

Ter-Minassian, Teresa, ed., 1997, Fiscal Federalism in Theory and Practice (Washington: International Monetary Fund). 